\title{
Nutritional content of different pretreated mushroom (Pleurotus florida) powders
}

\section{Tarun Kumar, Samsher, Suresh Chandra, Neelesh Chauhan, Gopal Singh and Vaishali}

Received : 27.07.2019; Revised : 29.08.2019; Accepted : 16.09 .2019

See end of the Paper for authors' affiliation

Correspondence to :

Tarun Kumar

Department of Agricultural

Engineering, Sardar Vallabhbhai

Patel University of Agriculture

and Technology, Meerut

(U.P.) India

Email : tarun.apfe@gmail.com
-ABSTRACT : Experiments were carried out to develop mushroom powder using oyster mushroom (Pleurotus florida) with three different treatments. Products were kept in pet jar during storage. Physico-chemical parameters like moisture, ash, fat, protein, crude fibre, sugar, carbohydrates, energy, fatty acids, minerals, vitamins etc. were evaluated. Investigation for organoleptic evaluation of the products was also performed during storage. On the basis of the experimental data it may be concluded that blanched mushroom powder samples contains minimum moisture, due to rapture of cells during blanching process. In most cases, values like ash, protein, fat, carbohydrates, sugar, energy and mostly vitamins; KMS treated samples were found superior over control and blanched samples. During organoleptic evaluation KMS treated mushroom powder sample got better score over other samples.

- KEY WORDS : Mushroom powder, Nutritional content, KMS, Sensory evaluation

- HOW TO CITE THIS PAPER : Kumar, Tarun, Samsher, Chandra, Suresh, Chauhan, Neelesh, Singh, Gopal and Vaishali (2019). Nutritional content of different pretreated mushroom (Pleurotus florida) powders. Internat. J. Agric. Engg., 12(2) : 256-260, DOI: 10.15740/HAS/IJAE/12.2/256260. Copyright@2019: Hind Agri-Horticultural Society. 